\title{
PENGARUH SUHU TEMPERING TERHADAP KEKUATAN TARIK, KEKERASAN DAN MIKROSTRUKTUR PADA SAMBUNGAN LAS SHIELDED METAL ARC WELDING (SMAW) BAJA PEGAS DAUN
}

\author{
Awan Jaya Miharja ${ }^{1}$, Sri Mulyo Bondan Respati ${ }^{2}$, Helmy purwanto ${ }^{2}$ \\ ${ }^{1}$ Mahasiswa Jurusan Teknik Mesin, Fakultas Teknik, Universitas Wahid Hasyim \\ ${ }^{2}$ Jurusan Teknik Mesin, Fakultas Teknik, Universitas Wahid Hasyim \\ Jl.Menoreh Tengah X/22, Sampangan, Semarang 50236. \\ Email: Awanjaya.m@Gmail.com
}

\begin{abstract}
Abstrak
Tujuan penelitian ini adalah untuk mengetahui pengaruh suhu tempering terhadap nilai kekuatan tarik, kekerasan dan struktur mikro pada hasil pengelasan elektroda E7018 dengan pengelasan shielded metal arc welding (SMAW). Lasan dilakukan tempering dengan variasi suhu $300^{\circ} \mathrm{C}, 450^{\circ} \mathrm{C}$ dan $600^{\circ} \mathrm{C}$. Hasil pengujian menunjukkan bahwa suhu temper $300^{\circ} \mathrm{C}$ mengasilkan kekuatan tarik tertinggi yaitu $78,752 \mathrm{~kg} / \mathrm{mm}^{2}$ dan kekerasan rata-rata yaitu 42,67 HRC, pada daerah HAZ memiliki kekerasan 42,50 HRC. Semakin tinggi suhu temper kekerasan akan semakin menurun. Pada daerah logam las kekerasan paling tinggi adalah spesimen dengan suhu temper $450^{\circ} \mathrm{C}$ yaitu 15,33 HRC. Pada suhu temper $300^{\circ} \mathrm{C}$ daerah logam induk dan daerah $H A Z$ yang terbentuk adalah berstruktur ferit dan martensit lebih rapat dan ferit widmanstatten, pada daerah logam las tampak ferit batas butir pada columnar grains terlihat lebih jelas dan merata pada pengaruh suhu temper $450^{\circ} \mathrm{C}$.
\end{abstract}

Kata kunci: kekerasan, kekuatan tarik, pengelasan, struktur mikro, tempering

\section{PENDAHULUAN}

Perkembangan pengelasan sangat pesat khususnya pada bidang kontruksi yang membutuhkan las untuk menggabungkan komponen. Proses pengelasan dibutuhkan dalam dunia industri, salah satunya bidang otomotif dalam perbaikan pegas daun pada mobil. Pegas daun mobil yang patah disambung kembali dengan cara dilas, hal itu dilakukan untuk menghemat biaya penggantian. Pengelasan adalah ikatan metalurgi pada sambungan logam atau logam paduan yang dilaksanakan dalam keadaan lumer atau cair Menurut DIN (Deutch Industrie Normen) artinya las adalah proses penyambungan setempat dari beberapa batang logam dengan menggunakan energi panas. Las SMAW disebut juga las busur listrik yang mampu mencairkan logam yang dilas, busur listrik dibangkitkan dari suatu mesin las (Wiryosumarto dan Okumura, 2000).

Perlakuan panas didefinisikan sebagai kombinasi perlakuan yang melibatkan pemanasan dan pendinginan yang diatur dengan tujuan untuk mendapatkan sifat sifat tertentu (Daryanto, 2010).

Tempering merupakan proses memanaskan kembali baja yang telah dipanaskan atau dikeraskan pada suhu dibawah suhu kritis disusul dengan pendinginan. Dengan proses temper ini ductilities dapat ditingkatkan namun kekerasan dan kekuatan akan menurun. Temper dimungkinkan oleh karena sifat struktur martensit yang tidak stabil (Djafrie, 1986).

Pengujian Kekuatan tarik dilakukan untuk mengetahui sifat mekanik dari material dapat diketahui dari kekuatan dan elastisitasnya untuk melengkapi informasi rancangan dasar kekuatan suatu bahan, pengujian kekerasan dilakukan untuk mengetahui sifat dari material memiliki ketahanan terhadap beban. Pengujian mikrostruktur salah satu cara untuk mengetahui susunan fasa pada suatu material dan bahan penyusunannya dengan teknik metalografi.

Padang dkk, (2014) salah satu cara untuk mengurangi permasalahan pada hasil lasan yaitu dengan perlakuan panas paska pengelasan (post welding heat treatment, PWHT). Pengaruh perlakuan panas hasil pengelasan dengan suhu $450^{\circ} \mathrm{C}$ menghasilkan kekuatan tarik (tensile strength) sambungan las semakin meningkat sedangkan diatas temperatur $450^{\circ} \mathrm{C}$ semakin menurun.

PWHT berpengaruh pada sifat mekanik pengelasan tidak sejenis austentic stainless steel dan baja karbon, nilai kekerasan pada HAZ stainless steel naik. Kekuatan tarik, kekuatan luluh pada sambungan las semakin meningkat 
pada PWHT temperatur $550^{\circ} \mathrm{C}$. (Duniawan dan ilman, 2012). Yogantoro, 2010 menyatakan bahwa kekerasan tertinggi hasil pengecoran medium carbon steel didapat pada proses temper $400^{\circ} \mathrm{C}$.

Penelitian ini bertujuan untuk mengetahui pengaruh suhu tempering terhadap nilai kekuatan tarik, kekerasan dan struktur mikro pada hasil pengelasan SMAW.

\section{METODE PENELITIAN}

Bahan yang digunakan dalam penelitian ini adalah Material yang digunakan adalah pegas daun kijang kapsul 2000, adapun elektroda yang digunakan adalah E7018. Setelah proses pengelasan maka spesimen dilanjutkan dengan perlakuan tempering dengan variasi suhu $300^{\circ} \mathrm{C}, 450^{\circ} \mathrm{C}$ dan $600^{\circ} \mathrm{C}$ dengan holding time 30 menit. Kemudian dibentuk menjadi spesimen uji tarik dengan standart ASTM E-8, seperti ditunjukkan Gambar 1, sedangkan diagram alir penelitian ditunjukkan pada Gambar 2.

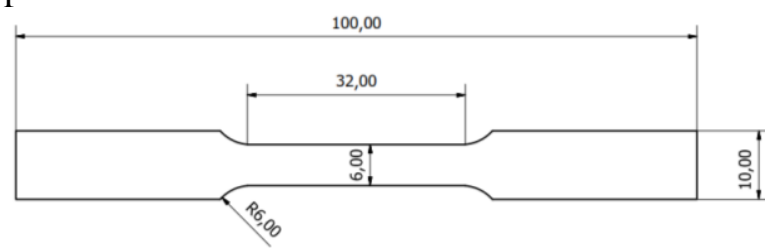

Satuan: mm

Gambar 1 Spesimen uji tarik
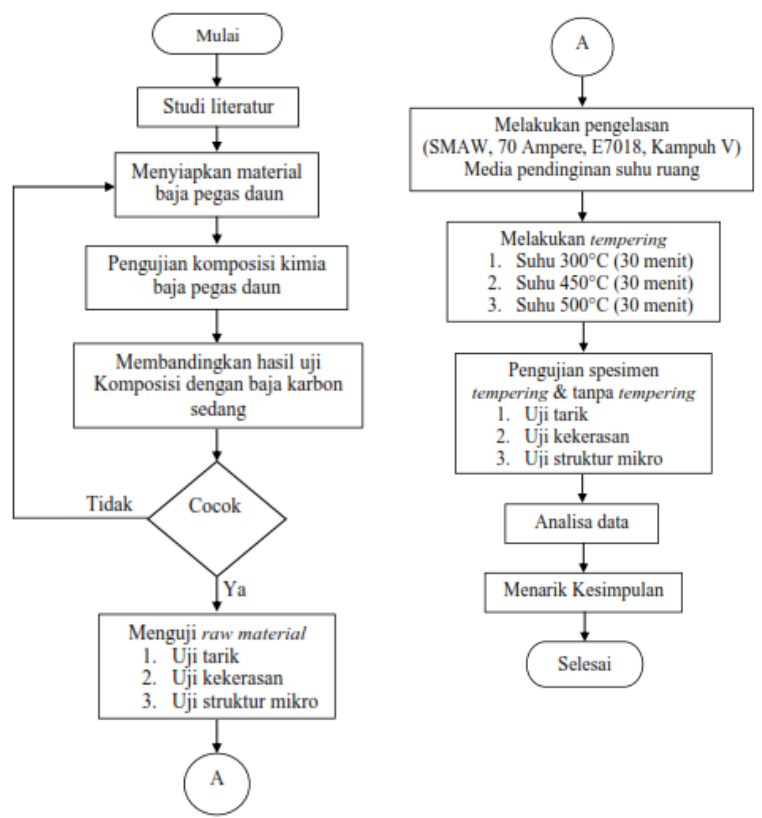
Media pendinginan suhu ruang

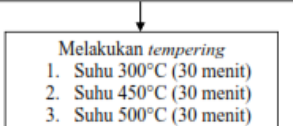
Suhu $500^{\circ} \mathrm{C}$ (30 menit)

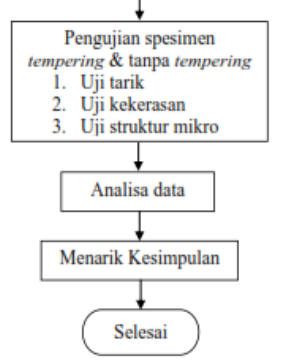

Gambar 2 Diagram alir penelitian

\section{HASIL DAN ANALISA}

\section{Hasil Analisa Uji Tarik}

Hasil pengujian tarik pada spesimen ditunjukkan pada Gambar 3 grafik tegangan tarik dan tegangan luluh.

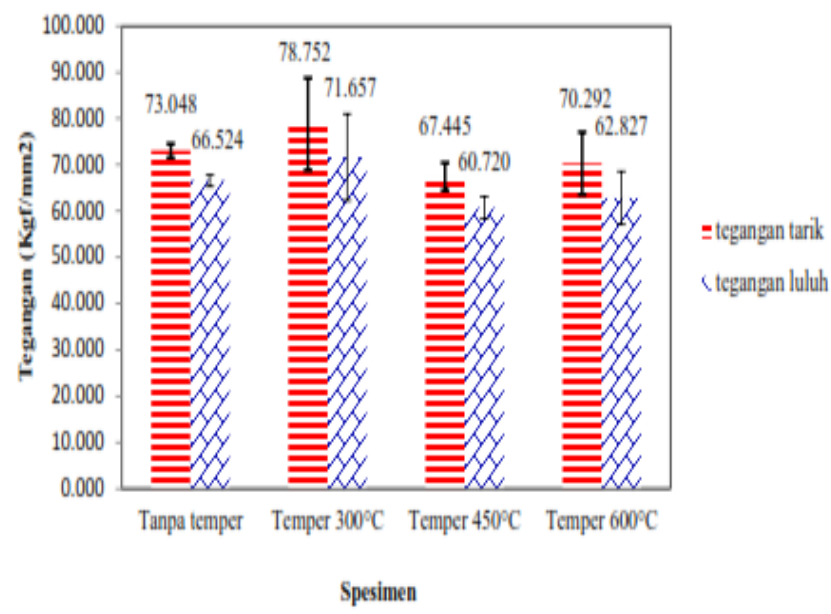

Gambar 3. Grafik tegangan tarik dan tegangan luluh

Pada Gambar 3 menunjukan bahwa pengelasan yang dilakukan dengan pendinginan udara yang dilanjutkan dengan penemperan $300^{\circ} \mathrm{C}$ memiliki kekuatan tarik paling tinggi yaitu $78,752 \mathrm{kgf} / \mathrm{mm}^{2}$ mengalami kenaikan 5,7 $\%$ dibandingkan nilai kekuatan tarik spesimen udara tanpa temper dengan nilai 73,048 $\mathrm{kgf} / \mathrm{mm}^{2}$, untuk nilai kekuatan spesimen udara temper $450^{\circ} \mathrm{C}$ yaitu $67,446 \mathrm{kgf} / \mathrm{mm}^{2}$ mengalami penurunan $11,31 \%$ dibandingkan dengan nilai kekuatan spesimen udara temper $300^{\circ} \mathrm{C}$, kemudian spesimen udara tempering $600^{\circ} \mathrm{C}$ dengan kekuatan tarik 70,292 $\mathrm{kgf} / \mathrm{mm}^{2}$ mengalami peningkatan kekuatan tarik sebesar 2,8 \% dibandingkan kekuatan tarik spesimen yang dilakukan temper $450^{\circ} \mathrm{C}$ tetapi masih lebih rendah dibandingkan dengan spesimen tanpa temper dan temper $300^{\circ} \mathrm{C}$.

Hasil kekuatan tarik pada spesimen temper $600^{\circ} \mathrm{C}$ mengalami kenaikan lagi setelah ditemper kemungkinan perubahan fasa yang lebih sempurna dibandingkan dengan spesimen temper $450^{\circ} \mathrm{C}$, proses terjadinya reaksi pemisahan atom karbon yang kurang sempurna juga sehingga berpengaruh pada tempering $600^{\circ} \mathrm{C}$, sehingga mengalami penurunan kekuatan tarik sebesar 2,8 \% dibandingkan spesimen temper $450^{\circ} \mathrm{C}$, sedangkan spesimen temper $450^{\circ} \mathrm{C}$ mengalami jumlah kekuatan tarik yang cukup tinggi yaitu 5,60\% dibandingkan dengan spesimen tanpa temper. Pengaruh sambungan las juga dapat berpengaruh pada 
kekuatan tarik, mungkin juga sambungan las pada spesimen temper $600^{\circ} \mathrm{C}$ lebih baik dibandingkan spesimen temper $450^{\circ} \mathrm{C}$ karena melihat struktur makro pada spesimen $450^{\circ} \mathrm{C}$ terdapat cacat yang dapat mempengaruhi kekuatan tarik.

Berbeda dengan hasil penelitian yang dilakukan (Padang, dkk., 2014) mengungkapkan bahwa pengaruh perlakuan panas hasil pengelasan, kekuatan tarik (tensile strength) pada sambungan las semakin meningkat pada temperatur $450^{\circ} \mathrm{C}$ dan diatas temperatur $450^{\circ} \mathrm{C}$ semakin menurun, hal ini karena adanya perubahan ukuran butir logam. maka hasil penelitian pada pengelasan baja pegas daun yang dilakukan temper berbeda ditunjukkan Gambar 3 bahwa hasil kekuatan tarik paling rendah dimiliki oleh spesimen yang dilakukan temper $450^{\circ} \mathrm{C}$

\section{Hasil Analisa Uji Kekerasan}

Setelah melakukan pengujian kekerasan dihasilkan data nilai kekerasan, data hasil pengujian kekerasan dapat dilihat pada Gambar 4 Grafik nilai rata rata kekerasan, terlihat bahwa hasil uji kekerasan logam induk rata-rata paling tinggi adalah spesimen yang dilakukan temper $300^{\circ} \mathrm{C}$ nilai kekerasannya yaitu 42,67 HRC dibandingkan spesimen dengan tanpa temper, temper $450^{\circ} \mathrm{C}$ dan $600^{\circ} \mathrm{C}$, pada daerah $\mathrm{HAZ}$ pun kekerasan paling tinggi adalah spesimen yang dilakukan temper $300^{\circ} \mathrm{C}$ dengan kekerasan $42,50 \mathrm{HRC}$ dan mengalami kenaikan kekerasan 0,17\% dibandingkan pada daerah logam induk, sedangkan pada daerah las kekerasan paling tinggi pada spesimen yang dilakukan temper $450^{\circ} \mathrm{C}$ yaitu 15,33 HRC dan mengalami kenaikan 2,33\% dibandingkan spesimen yang dilakukan temper $300^{\circ} \mathrm{C}$.

diketahui kekerasan raw material baja

pegas daun sebelum dilakukan perlakuan memiliki kekerasan yang rendah setelah dilakukan pengelasan kekerasan logam induk mengalami kenaikan, hal itu bisa disebabkan karena logam induk mendapat pengaruh dari heat input pada saat proses pengelasan karena pada saat pengambilan data jarak titik yang dilas dengan logam induk tidak terlalu jauh jaraknya atau juga bisa terkena pengaruh panas pada saat proses permesian dalam pembentukan spesimen. Untuk lebih jelas peningkatan dan penuruan kekerasan masing masing spesimen dapat ditunjukkan oleh Gambar 4 Grafik kekerasan pada masing masing daerah

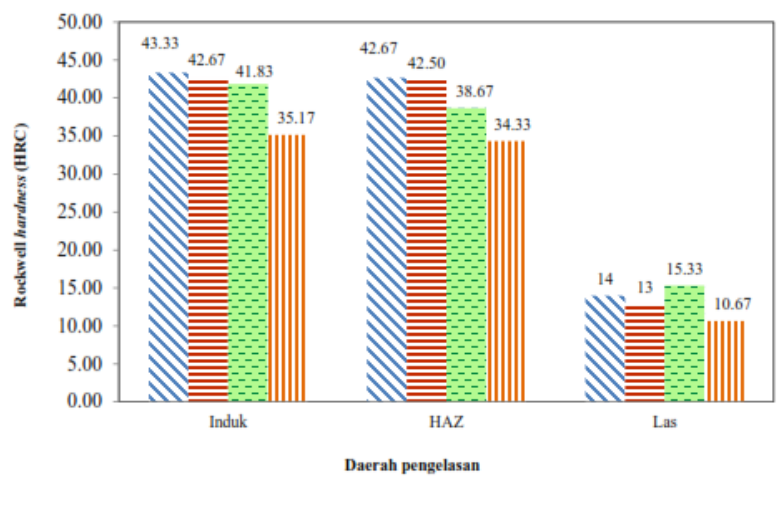

`Tanpa temper $=$ Temper $300^{\circ} \mathrm{C}=$ Temper $450^{\circ} \mathrm{C} \|$ Temper $600^{\circ} \mathrm{C}$

Gambar 4 Grafik nilai kekerasan

Dari Gambar 4 pada daerah logam induk spesimen yang dilakukan temper $300^{\circ} \mathrm{C}$ memiliki kekerasan paling tinggi yaitu 42,67 HRC dibandingkan dengan spesimen $450^{\circ} \mathrm{C}$ dengan kekerasan 41,83 HRC dan spesimen temper $600^{\circ} \mathrm{C}$ dengan kekerasan paling rendah yaitu 35,17 HRC pada daerah logam induk, sedangkan pada daerah HAZ spesimen temper $300^{\circ} \mathrm{C}$ masih memiliki kekerasan paling tinggi juga yaitu 42,50 HRC kemudian pada daerah HAZ perlakuan temper $450^{\circ} \mathrm{C}$ semakin rendah kekerasanya menjadi 38,67 HRC dan spesimen temper $600^{\circ} \mathrm{C}$ kekerasanya semakin turun yaitu 34,33 HRC, hal itu dikarena kan proses tempering akan mempengaruhi kekerasan seiring bertambahnya suhu semakin tinggi maka kekerasanya akan semakin rendah pada kedua daerah logam induk dan daerah HAZ.

Pada Gambar 4 terlihat bahwa hasil uji kekerasan pada daerah logam induk dan logam las menunjukkan pengaruh tempering yang akan mengakibatkan penurunan kekerasan kedua daerah tersebut, berbeda pada daerah logam las masing-masing spesimen, spesimen yang dilas dan dilakukan temper $450^{\circ} \mathrm{C}$ memiliki kekerasan paling tinggi yaitu 15,33 HRC, kekerasan yang diperoleh pada logam las itu juga dapat dipengaruhi oleh elektroda yang digunakan karena pada hasil kekerasan daerah logam las kekerasanya berbeda dipengaruhi oleh komposisi dari logam induk serta elektroda yang digunakan menurut (Rianto, dkk., 2014) elektroda E7018 mengandung Mn 1,6\% sehingga menimbulkan perbedaan komposisi kimia dengan logam induk sehingga mempengaruhi perbedaan kekuatan dari masing masing logam las yang dilakukan pengelasan. 
Bentuk dari butir butir logam yang dipengaruhi oleh arus listrik yang digunakan untuk menyambungkan logam dasar dengan elektroda yang akan mencair dan membentuk pada sambungan las juga dapat mempengaruhi kekuatan dan kekerasan dari sambungan las, jika arus listrik yang mengalir besar maka butir butir logam akan meenjadi halus dan jika arus listrik yang mengalir semakin besar butir butirakan terbakar sehingga sambungan menjadi rapuh.

Pada Gambar 4 juga dapat dilihat bahwa kekerasan dari spesimen yang dilas tanpa perlakuan temper memiliki kekerasan yang lebih tinggi dibandingkan dengan spesimen yang dilakukan temper $300^{\circ} \mathrm{C}, 450^{\circ} \mathrm{C}$ dan $600^{\circ} \mathrm{C}$ pada daerah logam induk hal itu bisa heat input karena proses pengelasan pada kedua daerah memiliki pengaruh besar pada perubahan struktur material spesimen tanpa temper

\section{Hasil Analisa Struktur Mikro}

\section{Struktur mikro daerah HAZ}

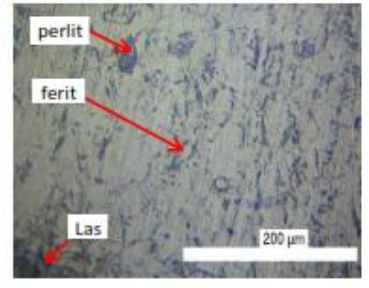

(A) HAZ tanpa temper

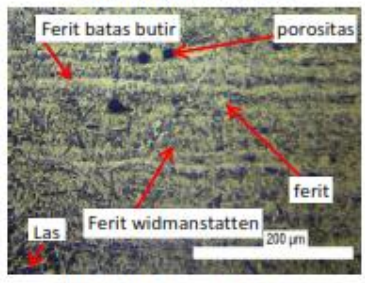

(C) HAZ temper $450^{\circ} \mathrm{C}$

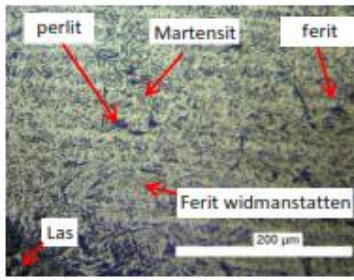

(B) $\mathrm{HAZ}$ temper $300^{\circ} \mathrm{C}$

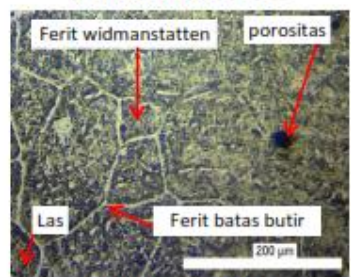

(D) HAZ temper $600^{\circ} \mathrm{C}$
Gambar 5 Daerah HAZ spesimen (A) HAZ tanpa temper (B) $\mathrm{HAZ}$ temper $300^{\circ} \mathrm{C}$ (C) HAZ temper $450^{\circ} \mathrm{C}$ (D) $\mathrm{HAZ}$ temper $600^{\circ} \mathrm{C}$

Dari hasil foto mikrostruktur pada daerah HAZ masing masing dapat diketahui struktur mikro, panas yang terjadi pada proses pengelasan menyebabkan terjadinya daerah HAZ, pada spesimen tanpa temper seperti terlihat pada Gambar 5 (A) tampak berstruktur ferit yang ditunjukkan berwarna putih yang paling mendominasi dan cenderung lunak sementara perlit yang berwarna gelap dan sedikit martensit karena dalam perlakuan panas pada pembuatan produk awalnya telah melalui proses panas kemudian terkena panas kembali oleh panas las.

Sedangkan pada Gambar 5 (B) hasil struktur mikro pada daerah HAZ dengan perlakuan temper $300^{\circ} \mathrm{C}$ struktur mikronya terdapat fasa martensit dan membuktikan laju pendinginan lebih cepat dibandingkan dengan spesimen yang dilakukan temper suhu $450^{\circ} \mathrm{C}$ dan $600^{\circ} \mathrm{C}$ martensit terlihat lebih rapat pada daerah HAZ spesimen temper $300^{\circ} \mathrm{C}$ berbentuk seperti jarum-jarum yang merata dan bagian pinggirnya berwarna kehitaman. Sedangkan fasa ferit masih mendominasi tetapi tidak rapat seperti yang ada pada Gambar 5 (A) selain itu pada spesimen temper $300^{\circ} \mathrm{C}$ terdapat sedikit perlit kasar dan terdapat ferit widmanstatten yang cukup banyak hal ini dijelaskan oleh peneliti sebelumnya Arifin, dkk., (2012) penambahan unsur pada logam las akan menimbulkan struktur mikro cenderung sedikit ferit batas butir, ukuran ferit batas butir akan meningkat jika waktu pendinginan yang lambat itu juga berlaku pada menjadi penyebab paling banyak menjadikan ferit widmanstatten selain itu kandungan oksigen juga bisa mempengaruhi.

Pada spesimen temper $450^{\circ} \mathrm{C}$ yang terlihat pada Gambar 5 (C) menunjukkan struktur lebih sedikit struktur widmanstatten dibandingkan spesimen temper $300^{\circ} \mathrm{C}$ dikarenakan pendinginan pada spesimen temper $450^{\circ} \mathrm{C}$ lebih lama dibandingkan spesimen temper $300^{\circ} \mathrm{C}$, pada Gambar 5 (C) menunjukkan adanya struktur ferit batas butir menurut Setiawan dan Wardana (2006) ferit batas butir karena adanya pengaruh heat input terhadap material logam las dan kemudian dilanjutkan pendinginan dengan laju pendinginan yang semakin lambat dan ada sedikit porositas yang tampak pada Gambar 5 (C) mungkin adanya kotoran yang terjebak pada saat pembuatan material.

Pada spesimen temper $600^{\circ} \mathrm{C}$ yang terlihat pada Gambar 5 (D) menunjukkan struktur yang mendominasi adalah ferit batas butir karena pada spesimen temper $600^{\circ} \mathrm{C}$ pendinginannya lebih lambat dibanding spesimen temper $300^{\circ} \mathrm{C}$ dan temper $450^{\circ} \mathrm{C}$ sehingga pada Gambar 5 (D) lebih banyak ferit batas butir di bandingkan Gambar 5 yang lainya, dan ferit pada spesimen temper $600^{\circ} \mathrm{C}$ lebih banyak dan jelas sehingga kekerasanya lebih rendah dibandingkan dengan spesimen temper lainya pada daerah HAZ. 


\section{Struktur mikro daerah las}

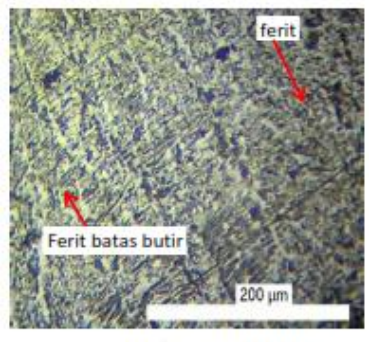

(A) Las tanpa temper

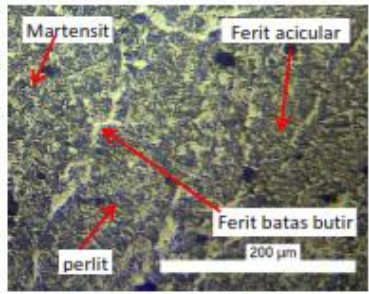

(C) Las temper $450^{\circ} \mathrm{C}$

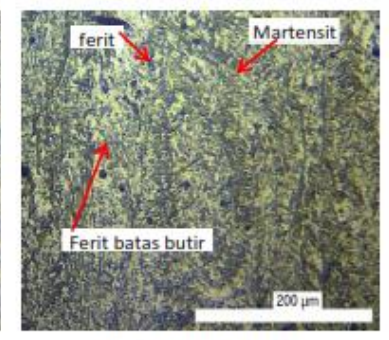

(B) Las temper $300^{\circ} \mathrm{C}$

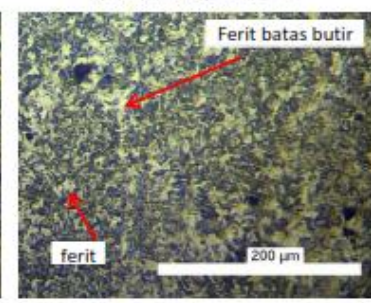

(D) Las temper $600^{\circ} \mathrm{C}$
Gambar 6 Logam las spesimen (A) Las tanpa temper (B) Las temper $300^{\circ} \mathrm{C}$ (C) Las temper $450^{\circ} \mathrm{C}$ (D) Las temper $600^{\circ} \mathrm{C}$

Dari hasil foto mikrostruktur pada daerah las pada masing-masing Gambar 5 dapat dilihat struktur penyusun pada spesimen, logam las terdiri dari logam induk dan bahan tambah dari elektroda karena logam las dalam pengelasan kemungkinan besar menjadi pemisah komponen yang menjadikan struktur tidak homogenya dan menimbulkan ferit kasar dan bainit yang menurunkan ketangguhan dan cenderung lunak dicirikan mikrostruktur logam las adalah columnar grains berasal dari logam induk. Pada Gambar 6 (A) struktur mikro daerah las tanpa temper tampak terdapat sedikit fasa ferit batas butir yang menurut Setiawan dan Wardana (2006) ferit batas butir karena adanya pengaruh heat input terhadap material logam las dan kemudian dilanjutkan pendinginan dengan laju pendinginan yang semakin lambat dan terlihat columnar grains di sekitar ferit batas butir. Ada juga sedikit fasa ferit yang tidak terlalu merata masih mendominasi dan mengakibatkan kekerasan menurun pada daerah lasan, sedangkan pada Gambar 6 (B) fasa ferit masih banyak dan besar disebabkan pendinginan yang lambat karena proses tempering dan pengaruh kandungan silikon yang tinggi sehingga kekerasan dari spesimen temper $300^{\circ} \mathrm{C}$ lebih rendah dibandingkan kekerasan spesimen tanpa temper. Ada juga sedikit fasa martensit yang berbentuk seperti pelat kecil seperti pada Gambar 6 (B) terbentuk karena pendinginan yang lebih cepat pada saat proses pengelasan dan biasanya pada baja yang memiliki kandungan karbon dibawah $0,6 \%$ C. serta juga ada fasa batas butir yang lebih besar dibandingkan Gambar 6 (A) sehingga kekerasan dari lebih rendah.

Pada Gambar 6 (C) tampak terlihat fasa batas butir lebih sedikit banyak dibandingkan spesimen temper $300^{\circ} \mathrm{C}$ pada Gambar 6 (B) mungkin karena pengaruh suhu temper yang lebih tinggi sehingga membutuhkan waktu pendinginan yang lebih lambat.. Serta ada sedikit fasa martensit yang berbentuk akibat terjebaknya karbida seperti pelat kecil pada Gambar 6 (C) yang mempengaruhi kekerasan pada logam las paling keras yaitu 15,33 HRC. Fasa perlit juga. Tampak juga sedikit ferit acicular yang diharapkan pada proses pengelasan karena struktur ini sebagai interlocking struktur yang mampu mengahambat perambatan retak, pada spesimen temper $450^{\circ} \mathrm{C}$ sehingga lebih keras dibandingkan kekerasan lainya.

\section{Struktur mikro logam induk}

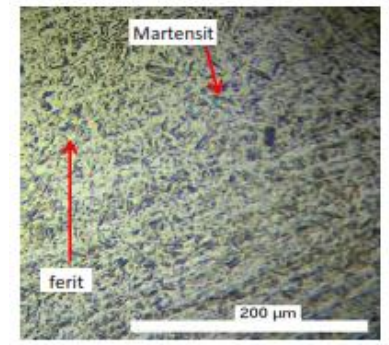

(A) induk tanpa temper

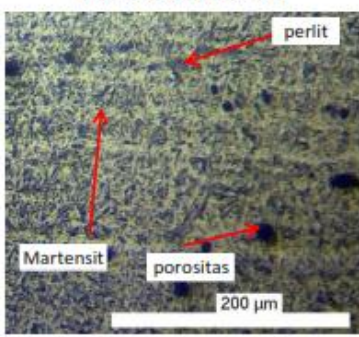

(C) induk temper $450^{\circ} \mathrm{C}$

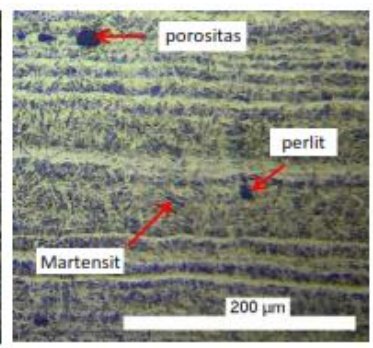

(B) induk temper $300^{\circ} \mathrm{C}$

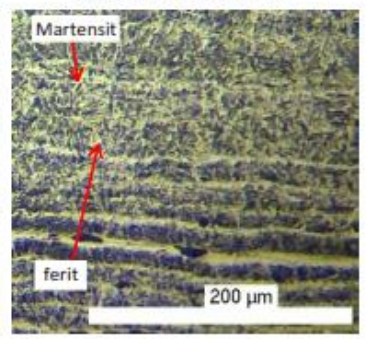

(D) induk temper $600^{\circ} \mathrm{C}$
Gambar 7 Logam induk spesimen (A) induk tanpa temper (B) induk temper $300^{\circ} \mathrm{C}(\mathrm{C})$ induk temper $450^{\circ} \mathrm{C}(\mathrm{D})$ induk temper $600^{\circ} \mathrm{C}$

Dari Gambar 7 (A) tampak berstruktur ferit dan martensit dan yang paling mendominasi adalah martensit yang berbentuk seperti jarum sedangkan perlit dan ferit banyak dan rapat berbeda dengan spesimen temper $300^{\circ} \mathrm{C}$ pada Gambar 7 (B) struktur mikronya tampak masih banyak martensit tetapi kurang rapat dan merata dan terlihat fasa perlit kasar sehingga pada logam induk spesimen temper $300^{\circ} \mathrm{C}$ memiliki kekerasan paling tinggi 
dibandingkan spesimen $450^{\circ} \mathrm{C}$ dan $600^{\circ} \mathrm{C}$ yaitu $42,67 \mathrm{HRC}$ dan pada spesimen temper $450^{\circ} \mathrm{C}$ yang tampak pada Gambar 7 (C) hampir sama dengan spesimen temper $300^{\circ} \mathrm{C}$ melainkan fasa martensit tidak begitu rapat dan fasa perlit cenderung lebih kasar dan pada kedua spesimen yaitu temper $300^{\circ} \mathrm{C}$ dan $450^{\circ} \mathrm{C}$ terlihat tampak ada porositas pada beberapa bagian spesimen disebabkan oleh proses pembuatan material mungkin juga karena material baja pegas daun yang sudah pernah dipakai sehingga menimbulkan cacat porositas. Pada Gambar 7 (D) fasa ferit yang berwarna putih mendominasi dan martensit lebih menyebar sehingga mempengaruhi kekerasannya. Pada Gambar 7 (D) tampak jelas garis putih memanjang seperti columnar mungkin disebabkan karena proses pembuatan material pegas daun dilakukan proses rolling sehingga tampak seperti Gambar 7 melainkan setelah proses tempering akan lebih tampak pada masing masing spesimen pengujian

\section{KESIMPULAN}

Berdasarkan hasil analisa kekuatan tarik, kekerasan dan struktur mikro, pada pengaruh suhu tempering setelah pengelasan dapat diambil kesimpulan yaitu:

1. Pengaruh perlakuan panas dengan variasi suhu tempering pada pengelasan kekuatan (tensile strength) paling tinggi dengan nilai $78,752 \mathrm{kgf} / \mathrm{mm}$ yaitu pada pengaruh suhu temper $300^{\circ} \mathrm{C}$ dan pengaruh suhu temper $450^{\circ} \mathrm{C}$ dengan nilai $67,445 \mathrm{kgf} / \mathrm{mm}$ serta pengaruh suhu $600^{\circ} \mathrm{C}$ dengan kekuatan tarik 70,292 $\mathrm{kgf} / \mathrm{mm}$. Kekuatan tarik setelah ditemper mengalami penurunan karena adanya perubahan ukuran butiran pada logam. sedangkan pada hasil pengujian kekerasan pada logam induk yang paling tinggi adalah spesimen las yang dilakukan tanpa temper yaitu 43,33 HRC dan pada perlakuan temper $300^{\circ} \mathrm{C}$ memiliki kekerasan paling tinggi diantara temper $450^{\circ} \mathrm{C}$ dan $600^{\circ} \mathrm{C}$ yaitu $42,67 \mathrm{HRC}$ dan pada daerah HAZ yang paling tinggi adalah spesimen yang dilakukan temper 42,50 HRC dan semakin turun pada pengaruh suhu temper $450^{\circ} \mathrm{C}$ dan $600^{\circ} \mathrm{C}$, sedangkan pada daerah lasan pengaruh suhu $450^{\circ} \mathrm{C}$ memiliki kekerasan tertinggi dengan nilai 15,33 dibandingakan dengan pengaruh suhu temper $300^{\circ} \mathrm{C}$ dan $600^{\circ} \mathrm{C}$ dan hasil itu berbanding terbalik dengan hasil kekuatan tarik pada pengaruh temper suhu $450^{\circ} \mathrm{C}$ yang memiliki kekuatan tarik paling rendah.

2. Pengaruh suhu temper pada struktur mikro pada hasil pengelasan yaitu pada daerah logam induk dengan pengaruh suhu temper $300^{\circ} \mathrm{C}$ tampak berstruktur ferit dan martensit lebih rapat dan merata dibandingkan dengan pengaruh suhu temper $450^{\circ} \mathrm{C}$ dan $600^{\circ} \mathrm{C}$, pada daerah heat affected zone (HAZ) juga sama pengaruh suhu temper $300^{\circ} \mathrm{C}$ terlihat martensit yang lebih merata dan ferit widmanstatten dibandingkan pengaruh suhu temper lainya sedangkan pengaruh suhu temper pada daerah logam las ferit batas butir pada columnar grains terlihat lebih jelas dan banyak dibandingkan pengaruh suhu temper $300^{\circ} \mathrm{C}$ dan $600^{\circ} \mathrm{C}$

Jadi pada penelitian ini untuk hasil yang paling mendekati nilai kekuatan tarik raw material adalah spesimen dengan perlakuan tempering $300^{\circ} \mathrm{C}$.

\section{DAFTAR PUSTAKA}

Daryanto., 2010. Proses pengolahan besi dan baja (ilmu metalurgi), cet 1 satu nusa, sarana tutorial nurani sejahtera, Bandung.

Djafrie, S., 1986. Metalurgi Mekanik. Terjemahan dari Mechanical Metallurgy. Jakarta: Erlangga

Duniawan, A., Ilman, M.N., 2012, "Pengaruh PWHT Terhadap Sifat Mekanik Sambungan Las Tak Sejenis Austenitic Stainless Steel Dan Baja Karbon", Prosiding seminar nasional aplikasi sains dan teknologi periode III, Yogyakarta

Padang, E.R., Leonard, J., dan Syam, R., 2014, "Analisis pengaruh perlakuan panas berdasarkan diagram TTT dan CCT terhadap sifat sifat mekanik hasil pengelasan baja karbon menengah dengan pengelasan SMAW”, Prosiding Seminar Nasional Rekayasa Material, Sistem Manufaktur Dan Energi, Universitas Hasanudin, Makassar.

Rianto, E., Suharno., Harjanto, B., 2014, Pengaruh temperatur Quenching Terhadap kekerasan dan ketangguhan Hasil pengelasan Baja keylos 50, Universitas sebelas maret. Surakarta 
Setiawan, A., Wardana, Y.A.Y., 2006," Analisa ketangguhan struktur mikro pada daerah las dan HAZ hasil pengelasan submerged ARC welding pada baja SM 490", Jurnal teknik mesin, vol 8, No.2, 5763. Yogyakarta.

Wiryosumarto, H., dan Okumura, T., 2000, Teknologi Pengelasan Logam, Cetakan kedelapan, Pradnya Paramita. Jakarta

Yogantoro A. 2010.: Penelitian Pengaruh Variasi Temperatur Pemanasan Low Tempering, Medium Tempering dan High Tempering pada Struktur Mikro, Kekerasan dan Ketangguhan. Tugas Akhir UMS. Surakarta. 